\title{
PENGARUH PERSEPSI SISWA TERHADAP KOMPETENSI PROFESIONAL GURU, PERHATIAN ORANG TUA DAN PEMANFAATAN WAKTU BELAJAR DI RUMAH DENGAN HASIL BELAJAR MATEMATIKA SISWA KELAS XI IPS SMAN 1 KUSAMBI
}

\author{
Darlin \\ Program Studi Sosiologi, Fakultas Ilmu Sosial dan Ilmu Politik \\ Institut Ilmu Sosial dan Ilmu Politik YAPIS Biak \\ alfindarlin@gmail.com
}

\begin{abstract}
Abstrak
Penelitian bertujuan untuk mengetahui: 1) Pengaruh kompetensi profesional guru terhadap prestasi belajar matematika siswa kelas XI IPS SMAN 1 Kusambi, 2) Pengaruh perhatian orang tua terhadap prestasi belajar matematika siswa kelas XI IPS SMAN 1 Kusambi, dan 3) Hubungan pemanfaatan waktu belajar siswa terhadap prestasi belajar matematika siswa kelas XI IPS SMAN 1 Kusambi. Sampel dari penelitian ini adalah sebagian dari siswa kelas XI IPS SMAN 1 Kusambi tahun ajaran 2017/2018 atau 35\% yaitu berjumlah 33 dari 80 siswa. Data dari penelitian ini dikumpulkan melalui instrument, angket dan dokumentasi, kemudian dianalisis dengan teknik stastitik deskriptif dan statistik inferensial menggunakan rumus regresi linear sederhana. Hasil penelitian ini menunjukan bahwa kompetensi Profesional guru berpengaruh terhadap prestasi belajar matematika sebesar 22,9\%. Perhatian orang tua berpengaruh terhadap prestasi belajar matematika sebesar 51,3\%. Dan pemanfaatan waktu belajar di rumah berpengaruh terhadap prestasi belajar matematika sebesar 49,4\%. Dari penelitian ini, dapat disimpulkan bahwa kompetensi profesional guru, perhatian orang tua, dan pemanfaatan waktu belajar di rumah dapat mempengaruhi prestasi belajar matematika siswa kelas XI IPS SMAN 1 Kusambi.
\end{abstract}

Kata Kunci: Kompetensi Profesional Guru, Perhatian Orang Tua, Waktu Belajar dan Hasil Belajar Matematika.

\section{PENDAHULUAN}

Dalam peningkatan hasil belajar siswa kompetensi guru sebagai tenaga pendidik baik secara personal, sosial maupun profesional harus dipersiapkan, dimana guru merupakan salah satu faktor penentu berhasil tidaknya suatu pembelajaran. Keberhasilan penyelengaraan pembelajaran sangat ditentukan oleh sejauh mana kesiapan guru dalam mempersiapkan peserta didiknya dalam kegitan pembelajaran. Apabila guru mempunyai kesiapan yang kurang, guru tersebut tidak dapat memberikan performa yang optimal, dan cenderung kurang bagus tersebut sehingga persepsi siswa terhadap guru tersebut menjadi negatif dan memandang rendah.

Selain kompetensi guru, perhatian orang tua juga berperan dalam upaya peningkatan hasil belajar siswa sesuai UUSPN pendidikan adalah tanggung jawab Antara keluarga, masyarakat dan pemerintah. Sekolah sebagai pembantu kelanjutan pendidikan dalam keluarga, sebab pendidikan pertama dan utama yang di peroleh anak adalah keluarga. Peralihan bentuk pendidik informal/keluarga ke formal/sekolah memerlukan kerjasama 
Antara orang tua dan sekolah. Dalam hal ini orang tua harus memperhatikan sekolah anaknya dengan memperhatikan dan menghargai usaha-usaha yang dilakukan oleh sang anak.

Dalam pendidikan, terdapat beberapa faktor yang mempengaruhi hasil belajar anak (siswa). Secara garis besar terbagi dua yaitu faktor internal dan faktor eksternal. Faktor internal merupakan faktor yang ada dalam diri siswa yang sedang belajar dimana terdiri dari faktor jasmani, faktor psikologi dan faktor kelelahan. Sedangkan faktor eksternal yang ada diluar diri siswa yang berasal dari sekolah, keluarga, masyarakat dan sumber belajar.

Dalam hal ini yang menjadi sasaran penelitian adalah faktor sekolah dan keluarga.

Sedangkan pada faktor keluarga yang menjadi sasaran penelitian adalah perhatian orang tua terhadap hasil belajar matematika siswa. Bentuk perhatian yang dimaksud adalah motivasi yaitu dengan memberikan dukungan moral kepada anak (siswa) pada saat anak mengalami kesulitan, dan fasilitas belajar dimaksudkan adalah fasilitas apa saja yang diberikan kepada anak (siswa) dalam hal kebutuhan sekolah.

Dan faktor keluarga lainnya yang menjadi sasaran penelitian yaitu pemanfaatan waktu belajar matematika di rumah adalah besarnya alokasi waktu belajar yang digunakan oleh siswa untuk mempelajari materi pelajaran, dan menyelesaikan latihan soal-soal baik secara mandiri maupun secara kelompok.

\section{METODE PENELITIAN}

Penelitian ini merupakan penelitian yang bersifat deskriptif kuantitatif dengan menggunakan metode penelitian (metode survey).

\section{Variabel Penelitian}

Variabel secara sederhana dapat diartikan ciri dari individu, obyek, gejala, dan peristiwa yang dapat diukur secara kuantitatif dan kualitatif. Adapun variabel dalam penelitian ini adalah sebagai berikut:

a. Variabel bebas (independen)

1) Kompetensi Profesional Guru

2) Perhatian Orang Tua

3) Penambahan Jam Belajar Di Rumah

b. Variabel terikat (dependen) adalah Hasil belajar

\section{Desain Penelitian}

Penelitian ini mengacu kepada dua jurnal pendidikan yaitu Ridaul Inayah dkk, 2013 tentang Pengaruh Kompetensi Guru, Motivasi Belajar, Dan Fasilitas Belajar Terhadap Prestasi Belajar Mata Pelajaran Ekonomi serta Bangun, 2008 tentang Hubungan Persepsi Siswa Tentang Perhatian Orang Tua, Kelengkapan Fasilitas Belajar, Dan Penggunaan Waktu Belajar Di Rumah Dengan Prestasi Belajar Ekonomi. Dengan adanya jurnal tersebut membuat peneliti ingin melakukan penelitian kembali untuk melihat tingkat keberhasilan penilitian yang telah dilakukan sebelumnya.

\section{Teknik Pengumpulan Data}

Teknik pengumpulan data yang digunakan dalam penelitian ini adalah sebagai berikut:

1. Observasi, yaitu pengamatan yang dilakukan di sekolah yang menjadi objek penelitian dalam hal ini SMAN 1 Kusambi dengan sasaran Kompetensi Guru, Perhatian Orang Tua dan Penambahan Jam Belajar Di Rumah bagi siswa. 
2. Instrumen adalah serangkaian pertanyaan yang digunakan untuk mengetahui sasaran kompetensi profesional guru dengan prestasi belajar matematika SMAN 1 Kusambi. Instrumen penelitian berupa alat yang dipakai dan dibuat dalam skala model likert, yang dinyatakan dalam empat kategori yaitu 1) Sangat sesuai/sangat baik, 2) Sesuai/Baik, 3) Kurang sesuai/Kurang baik, dan 4) Tidak sesuai/tidak baik sesuai dengan kondisi yang dihadapi oleh siswa.

3. Angket adalah suatu daftar yang berisikan rangkaia pertanyaan tertulis bagi siswa, mengenai perhatian orang tua dan pemanfaatan waktu belajar di rumah terhadap prestasi belajar matematika siswa. Pertanyaan yang digunakan dipenelitian ini adalah pertanyaan tertutup karena alternatif jawaban telah disediakan.

4. Dokumentasi, yaitu kegiatana untuk memperoleh data langsung dari tempat penelitian.

\section{HASIL DAN PEMBAHASAN}

Tabel I. Distribusi Frekuensi Nilai Variabel Kompetensi Profesional Guru

\begin{tabular}{|c|c|c|c|}
\hline $\begin{array}{c}\text { Rentang } \\
\text { Nilai }\end{array}$ & Kategori & Frekuensi & Persentase \% \\
\hline $5-10$ & Rendah & 0 & 0 \\
\hline $11-15$ & Sedang & 24 & 72,73 \\
\hline $16-20$ & Tinggi & 9 & 27,27 \\
\hline Jumlah & & $\mathbf{3 3}$ & $\mathbf{1 0 0}$ \\
\hline
\end{tabular}

Sumber Data : Hasil Analisis Data Tahun 2017
Dari Tabel 1 diperoleh data yakni 24 orang siswa atau (72,73\%) kompetensi rofesional guru berada pada kategori sedang yakni berada pada rentang nilai antara 11 15 , dari 9 orang siswa atau $(27,27 \%)$ kompetensi profesional guru berada pada kategori tinggi yakni berada pada rentang nilai 16 - 20. Maka dapat disimpulkan bahwa kompetensi profesional guru SMAN 1 Kusambi tergolong sedang.

\section{Tabel 2. Deskriptif Nilai Perhatian Orang} Tua

\begin{tabular}{|c|c|}
\hline Komponen Analisis & Nilai \\
\hline Jumlah Sampel & 33 \\
\hline Mean (rata-rata) & 47,83 \\
\hline Standar Deviasi & 6,91 \\
\hline Variansi & 6,9 \\
\hline Skor Tertinggi & 68 \\
\hline Skor Terendah & 17 \\
\hline Rentang Skor & 51 \\
\hline
\end{tabular}

Sumber Data : Hasil Analisis Data Tahun 2017

Berdasarkan dari Tabel 2 di atas, dapat diketahui bahwa skor rata-rata perhatian orang tua adalah 47,83 hasil dari skor keseluruhan dibagi jumlah sampel. Skor terendah adalah 17 dari skor minimal (terendah) yang bisa dicapai dan skor tertinggi yaitu 68 dari skor maksimal yang bisa dicapai. 
Tabel 3. Distribusi Frekuensi Nilai Variabel Perhatian Orang Tua

\begin{tabular}{|c|c|c|c|}
\hline $\begin{array}{c}\text { Rentang } \\
\text { Nilai }\end{array}$ & Kategori & Frekuensi & $\begin{array}{c}\text { Persentase } \\
\%\end{array}$ \\
\hline $17-34$ & Rendah & 3 & 9,09 \\
\hline $35-51$ & Sedang & 20 & 60,91 \\
\hline $52-68$ & Tinggi & 10 & 30,00 \\
\hline Jumlah & & $\mathbf{3 3}$ & $\mathbf{1 0 0}$ \\
\hline
\end{tabular}

Sumber Data : Hasil Analisis Data Tahun 2017

Dari Tabel 3 di atas diperoleh data yakni 20 orang siswa atau $(60,91 \%)$ perhatian orang tua siswa berada pada kategori sedang yakni berada pada rentang nilai antara 17 - 34, dari 10 orang siswa $(30,00 \%)$ berada pada kategori tinggi yakni berada pada rentang nilai $52-68$, sedangkan 3 orang siswa atau $(9,09 \%)$ berada pada kategori rendah dengan rentang nilai yakni 17 - 34. Maka dari hasil yang didapatkan maka disimpulkan bahwa perhatian orang tua siswa kelas XI IPS SMAN 1 Kusambi tergolong sedang.

Tabel 4. Distribusi Frekuensi Nilai Pemanfaatan Waktu Belajar Di Rumah

\begin{tabular}{|c|c|c|c|}
\hline $\begin{array}{c}\text { Rentang } \\
\text { Nilai }\end{array}$ & Kategori & Frekuensi & $\begin{array}{c}\text { Persentase } \\
\%\end{array}$ \\
\hline $25-50$ & Rendah & 7 & 21,21 \\
\hline $51-75$ & Sedang & 22 & 66,67 \\
\hline $76-100$ & Tinggi & 4 & 12,12 \\
\hline Jumlah & & $\mathbf{3 3}$ & $\mathbf{1 0 0}$ \\
\hline
\end{tabular}

Sumber Data : Hasil Analisis Data Tahun 2017
Dari Tabel 4 diperoleh data yakni 22 orang siswa atau $(66,67 \%)$ pemanfaatan waktu belajar di rumah oleh siswa berada pada kategori sedang yakni berada pada rentang nilai antara $51-75$, dari 7 orang siswa atau $(21,21 \%)$ pemanfaatan waktu belajar di rumah oleh siswa berada pada kategori rendah yakni berada pada rentang nilai 25 - 50, sedangkan 4 orang siswa atau $(12,12 \%)$ berada pada kategori tinggi dengan rentang nilai yakni 76 - 100. Maka dapat disimpulkan bahwa pemanfaatan waktu belajar di rumah yang dilakukan oleh siswa kelas XI IPS SMAN 1 Kusambi tergolong sedang.

Tabel 5. Deskriptif skor hasil belajar siswa

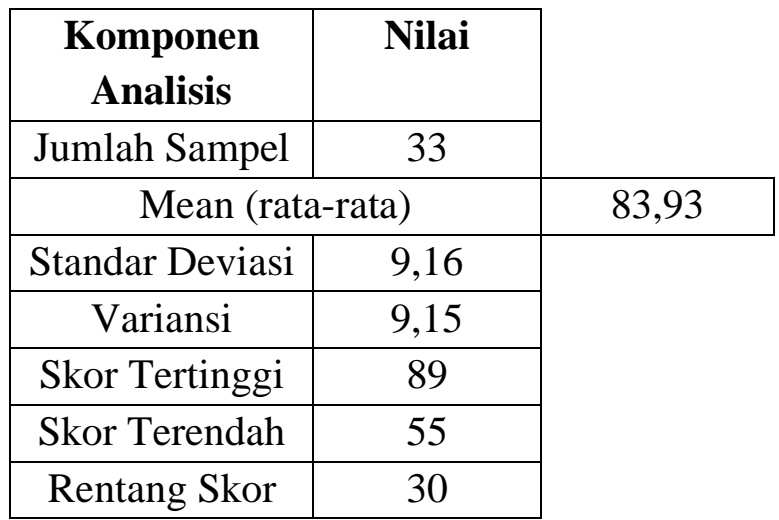

Sumber Data : Hasil Analisis Data Tahun 2017

Berdasarkan dari Tabel 5 di atas, dapat diketahui bahwa skor rata-rata hasil belajar siswa adalah 83,93 hasil dari skor keseluruhan dibagi jumlah sampel. Skor terendah adalah 55 dari skor minimal (terendah) yang bisa dicapai dan skor tertinggi yaitu 89 dari skor maksimal yang dicapai. 
Tabel 6. Deskriptif Skor hasil belajar siswa

\begin{tabular}{|c|c|c|c|}
\hline $\begin{array}{c}\text { Rentang } \\
\text { Nilai }\end{array}$ & Kategori & Frekuensi & $\begin{array}{c}\text { Persentase } \\
\%\end{array}$ \\
\hline $55-65$ & Rendah & - & - \\
\hline $66-80$ & Sedang & 18 & $54,55 \%$ \\
\hline $81-90$ & Tinggi & 15 & $45,45 \%$ \\
\hline Jumlah & & 33 & $100 \%$ \\
\hline
\end{tabular}

Sumber Data : Hasil Analisis Data Tahun 2017

Dari tabel 6 diperoleh data yakni 18 orang siswa atau $(54,55 \%)$ hasil belajar matematika siswa berada pada kategori sedang yakni berada pada rentang nilai antara 66 - 80, dari 15 orang siswa atau $(45,45 \%)$ hasil belajar matematika siswa berada pada kategori tinggi yakni berada pada rentang nilai 81 - 90, sedangkan kategori rendah dengan rentang nilai yakni 55 - 65. Maka dapat disimpulkan bahwa hasil belajar matematika siswa kelas XI IPS SMAN 1 Kusambi tergolong sedang.

Berdasarkan dari data hasil uji hipotesis, terdapat pengaruh yang signifikan sebagai penghubung antara kompetensi profesional guru terhadap hasil belajar matematika (sig. $0,000 \leq 0,05$ ) sehingga tidak ada alasan untuk menghapus pengaruh tersebut. Hal tersebut dikarenakan terdapat pengaruh langsung kompetensi profesional guru dengan hasil belajar matematika, yaitu sebesar 0,229 $=22,9 \%$.

Berdasarkan hasil analisis yang telah dilakukan, diketahui bahwa terdapat pengaruh signifikan yang menghubungkan antara perhatian orang tua dengan hasil belajar mata pelajaran matematika (sig. = $0,001 \leq 0,05)$. Dari hasil ini menunjukan bahwa terdapat pengaruh langsung perhatian orang tua dengan hasil belajar pada mata pelajaran matematika, yaitu $0,513=51,3 \%$.

Dari hasil pengujian hipotesis menunjukan bahwa terdapat pengaruh yang signifikan yang menghubungkan variabel pemanfaatan waktu belajar di rumah dengan hasil belajar matematika. Hal ini dibuktikan dengan hasil dari uji hipotesis yaitu $\mathrm{F}_{\text {hitung }} \geq$ $\mathrm{F}_{\text {Tabel }}=2,140 \geq 2,040$ dengan sig. $0,001 \geq$ $0,05 \%$. Dari hasil ini menunjukan bahwa terdapat pengaruh langsung perhatian orang tua dengan hasil belajar pada mata pelajaran matematika, yaitu 0,494 $=49,4 \%$.

Berdasarkan dari hasil analisis data, setiap variabel bebas menunjukan data yang signifikan tetapi mempunyai pengaruh yang berbeda-beda terhadap variabel terikat. Hal ini dikarenakan masih ada faktor-faktor lain yang mempengaruhi hasil belajar siswa.

a. Faktor internal

1) Faktor fisiologi berupa fisik)
a) Faktor sakit
b) Faktor kurang sehat
c) Faktor cacat tubuh

2) Faktor psikologi
a) Intelegensi
b) Bakat
c) Minat
d) motivasi

b. Faktor eksternal

1) Keadaan ekonomi orang tua

2) Hubungan Antara anggota keluarga

3) Lingkungan sekolah

4) Faktor media massa dan lingkungan sosial

\section{KESIMPULAN}

Berdasarkan hasil analisis penelitian dan pembahasan, dapat diperoleh beberapa kesimpulan anatara lain :

1. Terdapat pengaruh yang signifikan kompetensi profesional guru dengan hasil belajar matematika siswa kelas XI 
SMAN 1 Kusambi sebesar 0,229 $(22,9 \%)$. Berarti hipotesis diterima, kompetensi profesioanal guru memiliki pengaruh yang rendah terhadap hasil belajar matematika siswa kelas XI IPS SMAN 1 Kusambi.

2. Terdapat pengaruh yang signifikan perhatian orang tua dengan hasil belajar matematika siswa kelas XI IPS SMAN 1 Kusambi sebesar 0,513 (51,3\%), Hal ini berarti hipotesis diterima, perhatian orang tua memiliki pengaruh yang sedang terhadap hasil belajar matematika siswa kelas XI IPS SMAN 1 Kusambi.

3. Terdapat hubungan yang signifikan dalam pemanfaatan waktu belajar di rumah dengan hasil belajar matematika siswa kelas XI IPS SMAN 1 Kusambi sebesar 0,494 (49,4\%), Hal ini berarti hipotesis diterima, pemanfaatan waktu belajar di rumah memiliki pengaruh yang rendah terhadap hasil belajar matematika siswa kelas XI IPS SMAN 1 Kusambi.

\section{DAFTAR PUSTAKA}

Ahmadi, Abu. 1998. Psikologi Umum. Rineka Cipta. Jakarta.

2004. Pengelolaan Pengajaran. Rineka Cipta. Jakarta.

Ahmadi, Abu dan Supriono, Widodo, 1991. Psikologi Belajar. Rineka Cipta. Jakarta.

Anggraini, Erin. 2013. Hubungan Minat Belajar dan Fasilitas Belajar Siswa Dengan Prestasi Belajar Sosiologi Siswa Kelas XI IPS SMAN 3 Surakarta. UNSA
Arikunto, Suharsimi. 2006. Metodologi Penelitian. Bina Aksara. Yogyakarta.

Asmani, Jamal Ma'mur. 2009. Kompetensi Guru Menyenangkan dan Profesional. Power Books (IHDINA). Yogyakarta.

Bangun, Darwin. 2008. Hubungan Persepsi Siswa Terhadap Perhatian Orang Tua, Kelengkapan Fasilitas Belajar, Dan Penggunaan Waktu Belajar Di Rumah Dengan Prestasi Belajar Ekonomi. Jurnal Ekonomi dan pendidikan Volume 5 Nomor 1. Unila.

Casdasari, Mayis. 2004. Pengaruh Perhatian Orang Tua dan Minat Belajar Dengan Prestasi Belajar Siswa. (Penelitian Yang Dikhususkan Pada Prestasi Belajar Pilihan Program Ilmu Pengetahuan Alam Kelas II SMA PGRI 2 Kajen Kabupaten Pekalongan Tahun Pelajaran 2004/2005). UNY

Chairiah, Siti. 2010. Efektivitas Pendidikan Dan Latihan Profesi Guru (Plpg) Dalam Menunjang Profesionalisme Guru (Studi Kasus pada Guru SMP Muhammadiyah 22 Setiabudi Pamulang Tangerang - Banten). Skripsi UIN Syarif Hidayatullah. Jakarta.

Daryanto. 2013. Penilaian Kinerja Profesi Guru dan Angka Kreditnya. Gavamedia. Yogyakarta.

Depdiknas. 2000. Panduan Manajemn Sekolah. Direktorat Sekolah Lanjutan Tingkat Pertama. Jakarta.

Depdiknas. 2001. Pembinaan Personil Guru Dan Psikologi Pembinaan 
Personalia. Ditjen Dikdasman. Jakarta.

Depdiknas. 2005. Undang-undang Nomor 14 Tahun 2005 tentang guru dan Dosen. Depdiknas. Jakarta.

Eva Myrbeng \& Monica Rosen. 2003. The Impact of Teacher Competence in Public and independent Schools in Sweden. Gothenbung University. Sweden

Fattah, Nanang. 1996. Landasan Manajemen Pendidikan. Remaja Rosda Karya. Bandung.

Hadi, Sutrisno. 1986. Metode Research. Yogyakarta Fakultas Psikologi UGM. Jakarta.

Hakim, Thursman. 1992. Belajar Secara efektif. Puspa Swara. Jakarta.

Hamalik, Oemar. 1993. Metode Belajar dan Kesulitan-Kesulitan Belajar. Tarsilo. Bandung.

Hasbullah. 2006. Rahasia Sukses Belajar. Raja Grafindo Persada. Jakarta.

Inayah, R., Mariono, T., Sawiji, Hery. 2013. Pengaruh Kompetensi Guru, Motivasi Belajar Siswa, Dan Fasilitas Belajar Terhadap Prestasi Belajar Mata Pelajaran Ekonomi Pada Siswa Kelas XI IPS SMA Negeri 1 Lasem Jawa Tengah Tahun Pelajaran 2011/2012. Jurnal Pendidikan Insan Mandiri: Volume 1 Nomor 1. Jawa Tengah.

Kartono, Kartini. 1985 (a). Bimbingan Belajar di SMA dan Perguruan Tinggi. CV Rajawali. Jakarta. 1985 (b). Peran Keluarga

Dalam Membantu Anak . CV Rajawali. Jakarta.
Kunandar. 2007. Guru Profesional, Implementasi Kurikulm Tingkat Satuan Pendidikan (KTSP) dan Sukses dalam Sertifikat Guru. PT. Raja Grafindo Persada. Jakarta.

Marzuki, Saleh. 2010. Pendidikan Nonformal, Dimensi dalam Keaksaraan Fungsional, Pelatihan, dan Andragogi. Remaja Rosdakarya. Bandung.

Nazir Moh. 2011. Metode Penelitian. PT Ghalia Indonesia. Bogor.

Nugraha, Artana Sandra. 2011. Pengaruh Kompetensi Guru dan Fasilitas Belajar Terhadap Prestasi Belajar Siswa Kelas XI IPS MAN Malang 1. Skripsi Fakultas Tarbiyah UIN Maulana Malik Ibrahim. Malang. (Unpublished).

Nurrofiah, Dewi. 2006. Pengaruh Persepsi Siswa Tentang Iklim Sekolah Dan Perhatian Orang Tua Terhadap Prestasi Belajar Ekonomi Akuntasi. Unila.

Palili, Anna. 2002. Hubungan Pemanfaatan Waktu Belajar Di Rumah Dengan Hasil Belajar Fisika. Skripsi. Makassar.

Peraturan Menteri Pendidikan Nasional Nomor 16 Tahun 2007 Tentang Standar Kualifikasi dan Kompetensi Guru. Dirtjen Dikdasmen. Jakarta.

Peraturan Menteri Negara Pendayagunaan Aparatur Negara dan Reformasi Birokrasi Nomor 16 Tahun 2009 Tentang Standar Kualifikasi dan Kompetensi Guru. Dirtjen Dikdasmen. Jakarta. 
Salam, Burhanuddin. 1996. Pengantar Pedagogik, Dasar-dasar Ilmu Mendidik. Rineka Cipta. Bandung.

Siswoyo, Dwi., Hadisusanto, D., Sidaharto, D. 2008. Ilmu Pendidikan. UNY Press. Yogyakarta.

Slameto. 2004. Belajar dan Faktor-Faktor Yang Mempengaruhinya. Rineka Cipta. Jakarta.

Sofyan. 2012. Kontribusi Pengetahuan Dan Sikap Siswa Terhadap Perilaku Lingkungan Hidup (Studi Kasus Siswa Kelas XII IPS SMA 4 Watampone). Tesis UNM Pasca Sarjana. Makassar.

Sugiono. 2010. Metode Penelitian Pendidikan. Alfabeta. Bandung.

Surya, Hendra. 2004. Kiat Mengatasi Kesulitan Belajar (Bagi Pelajar dan Mahasiswa). PT Raja Grafindo Persada. Jakarta.

Suryabrata, Sumadi. 2001. Proses Belajar Mengajar Di Perguruan Tinggi. PT Raja Grafindo Persada. Jakarta.

Sudjana, Nana. 2001. Penelitian Prestasi Belajar Ekonomi Mengajar. PT. Remaja Rosdakarya. Bandung

Suharyono, Moch. Amien. 1994. Filsafat Geografi. Proyek dan Peningkatan Mutu Tenaga Kependidikan Dikti. Jakarta.

Swardi. 2008. Inovasi Pendidikan, dalam Upaya Peningkatan Profesionalisme Tenaga Kependidikan. Pustaka Setia. Bandung.

Syafril, Zelhendri Zen. 2012. Pengantar Pendidikan. Sukanbina Press. Padang.
Syah, Muhibbin. 2007. Psikologi Belajar. PT Raja Grafindo Persada. Jakarta.

$\begin{array}{lrr} & 2008 . & \text { Psikologi } \\ \text { Pendidikan. } & \text { PT. } & \text { Remaja } \\ \text { Rosdakarya. Bandung. } & \end{array}$
Pendidikan dan Pendekatan Baru. PT. Remaja Rosdakarya. Bandung.

Syaiful Bahri, Djamarah. 2002. Psikologi Belajar. Rineka Cipta. Jakarta.

Tilaar. 2000. Paradigma Baru Pendidikan Nasional. Rineka Cipta. Jakarta.

Tirtanegoro, Sutratinah. 1999. Anak Supernormal dan Pendidikannya. Rineka Cipta. Jakarta.

Tyas, Nur Budi Wahyu Ning, 2010. Pengaruh Kompetensi Guru dalam Proses Belajar Mengajar dan Fasilitas Belajar Terhadap Prestasi Belajar Mata Pelajaran ekonomi Pada Siswa Kelas X Sma Negeri 1Jekulo. Skripsi. Semarang. (Abstr).

Undang-Undang No. 20 Tahun 2003 tentang Sistem Pendidkan Nasional. Sinar Grafika. Jakarta

Undang-Undang RI. 2005. Sistem Pendidikan Nasional. Dirtjen Dikdasmen. Jakarta.

Undang-Undang RI No 14 tahun 2005. Tentang Guru dan Dosen. Sinar Grafika. Jakarta

Usman, Uzer.M. 2005. Menjadi Guru Profesional. Pt. Remaja Rosdakarya. Bandung.

Yumming. 2001. Korelasi Antara Prestasi Belajar IPA Fisika Siswa Dengan Kepedulian Orang Tua Terhadap Pembangunan Anak-Anak Mereka di 
SLTPN 2 Duampanua Pinrang.

Skripsi. Makassar.

Zaenab.S, Syahbudin. 2015. Pengantar Menejemen, Pendidikan, Praktis, Teori dan Aplikasi. CV. Budi Utama. Yogyakarta

Zamania, Indah Zakiyah. 2009. Upaya Peningkatan Kompetensi Guru Dalam Proses Belajar Mengajar Di Raudlatul Athfal Al-Ikhlas Sukodadi Lamongan. Skripsi UIN Maulana Malik. Malang. 